\title{
Weapons, Security, \& Oppression: \\ A Normative Study of International Arms Transfers ${ }^{1}$
}

\begin{abstract}
James Christensen
Final version available here: $\underline{\text { http://onlinelibrary.wiley.com/doi/10.1111/jopp.12045/abstract }}$
\end{abstract}

In recent years a number of philosophers have begun proposing normative principles to regulate international trade. ${ }^{2}$ A fundamental question which must be addressed by any normative account of international trade concerns what can be traded, and with whom. That this question is worth asking reflects the fact that the moral permissibility of trading certain commodities, and the moral permissibility of trading certain commodities with particular agents, is contested. Controversy surrounds transfers of hazardous waste from rich to poor countries ${ }^{3}$; the sale of emissions permits ${ }^{4}$; the purchase of natural resources from tyrannical regimes ${ }^{5}$; and a variety of other international exchanges. In this paper I explore the ethical dimensions of one controversial international trade, namely, the arms trade. The arms trade merits attention for a number of reasons. First, it has been largely neglected by political philosophers. While various aspects of international trade have recently been subjected to philosophical scrutiny, the arms trade has been virtually ignored. ${ }^{6}$ Second, the arms trade bears heavily on the achievement of basic needs, that is, needs which must be met if an individual is to lead a minimally decent life. More specifically, the arms trade bears on the achievement of security. All weapons have the capacity to incapacitate, injure, and kill: in short, all weapons have the capacity to cause serious physical harm. Furthermore, they are purchased because they have that capacity. Their capacity to cause serious physical harm makes trade in these commodities particularly controversial, and particularly worthy of philosophical inquiry. Third, the arms trade is politically salient. Since the terrorist attacks of September 11 2001, the US government has drastically ramped up arms sales to oppressive regimes regarded as valuable allies in the 'war on terror', and in the years since the 
Arab Spring large quantities of weapons have been transferred to rebel groups seeking to topple despotic rulers. It is thus important to question whether such transfers can be justified.

The paper unfolds as follows. In the first section I introduce the notion of a right to security, and show that that right can play a central role in justifying the arms trade. I then move on to show that the right to security can also ground a prima facie case for restricting the arms trade in certain ways. More specifically, I argue that the right to security grounds a prima facie case for the claim that states are duty-bound to refrain from trading certain types of weapons, and to refrain from selling weapons to regimes which exhibit an oppressive character. Section II explicates, and responds to, an argument commonly used to defend the sale of arms to oppressive regimes. According to this argument, states have a special duty to protect the security of their citizens, and discharging that duty will sometimes involve providing weapons to those oppressive regimes which are well placed to suppress terrorist threats. In section III I consider, and rebut, two further objections to the claim that states must refrain from selling weapons to oppressive regimes. The first argument appeals to the claim that arms sales to oppressive regimes can pave the way to improvements in the human rights practices of those regimes, while the second appeals to the claim that oppressive regimes will inevitably acquire weapons from somewhere. In section IV I consider the permissibility of supplying weapons to rebel groups engaged in revolutionary war against an oppressive regime. I argue that while supporting such groups may be permissible, or even required, supporting them by providing arms is, from a moral perspective, highly problematic.

When I use phrases like 'states are duty-bound to refrain from selling weapons to X' I shall mean both that states are themselves duty-bound to refrain from selling weapons to $\mathrm{X}$, and that states are duty-bound to prevent their citizens (e.g. their arms companies) from selling weapons to $\mathrm{X}$. While it is plausible to think that states are required to refrain from doing certain things which their citizens are permitted to do, I take it that the reasons I adduce in support of 
the claim that states are duty-bound to refrain from making certain arms transfers also support the claim that citizens are duty-bound to refrain from making those transfers. I also take it that the duties borne by citizens can permissibly be enforced by the state. The duties I identify are conceived of as duties of justice, and, more specifically, as duties to refrain from engaging in activities which violate the (security) rights of others. I endorse the standard view that such duties may be coercively enforced.

\section{I.}

It is natural to feel instinctively uneasy about the existence of markets in weapons, and some activists call for the arms trade to be completely abolished. ${ }^{7}$ While this stance is, perhaps, understandable, it is, I think, ultimately misguided: an ethically defensible arms trade is possible. The first step in my argument for this claim is to note that all persons have a right to security, or, perhaps more accurately, that all persons have a cluster of security rights: rights not to be assaulted, tortured, raped, killed, and so forth. In short, all persons have a right to physical safety. ${ }^{8}$ As Henry Shue has observed, no one would be willing to deny that all persons possess this minimal right. ${ }^{9}$ The right to security generates a variety of correlative duties. For now, notice that it puts states under a duty to protect the security of their citizens. The next important step in the argument is to point out that, in order to discharge this duty, states need weapons (or at least that in all realistically imaginable scenarios they need weapons). Without weapons, states would be unable to protect their citizens from armed aggressors (armed criminals, terrorist groups, belligerent regimes, etc.). Weapons enable states to both deter and repel such threats, and thus to protect their citizens' security.

It might be said that, in theory, states could protect their citizens' right to security not by acquiring weapons with which to deter and repel armed aggressors, but rather by bringing about the worldwide abolition of weapons. There are multiple reasons for dismissing this claim. First, and most obviously, bringing about the worldwide abolition of weapons is not an option that is 
realistically available to states. Second, even if states agreed to mutual disarmament there would always be the very real possibility that certain states would secretly retain their arsenals. And, third, even if mutual disarmament was achieved at time $\mathrm{T}$, there would always be the very real possibility that certain states would (perhaps secretly) rearm at time $\mathrm{T}+\mathrm{n}$. When a state disarms, it leaves itself and its citizens vulnerable, even if other states have also agreed to disarm.

Now, some states lack the capacity to produce their own weapons, or at least to produce weapons of adequate quality and in sufficient quantities. Consequently, in order to acquire weapons of adequate quality and in sufficient quantities, and to discharge their duty to protect the safety of their citizens, such states must import weapons from abroad. If these states were unable to import weapons - if no international trade in weapons was permitted - they would not be able to ensure the security of their citizens. Blocking all international arms transfers would penalize states which lack the capacity to produce their own weapons, and unjustifiably jeopardize the security of the people who live in those states. ${ }^{10}$

The argument presented in the previous paragraph establishes that international trade in (at least certain kinds of) weapons can be morally permissible when it consists in transfers to states which lack the capacity to produce weapons (of adequate quality and in sufficient quantities), and which import weapons in order to discharge their duty to protect their citizens' security. But a great many international arms transfers are not of this kind. For most of the $20^{\text {th }}$ Century, the largest arms exporters mainly sold weapons to other economically developed countries $^{11}$, most of which, by virtue of being economically developed, presumably either possessed or could acquire the capacity to produce weapons of adequate quality and in sufficient quantities. The argument presented above does not explicitly vindicate these kinds of transfers, but it does provide the resources needed to do so. It establishes that weapons have a legitimate function, viz. they enable states to discharge their duty to protect the security of their citizens. And if weapons have a legitimate function, it is hard to see why trade in weapons would only be 
morally permissible when it consists in transfers to states which lack the capacity to produce weapons of their own. If a state possesses the capacity to produce its own weapons, but has a comparative disadvantage in weapons manufacturing, it makes sense for that state to purchase weapons from abroad and to devote the resources it would have otherwise used to manufacture weapons to alternative lines of production. If weapons have a legitimate function, then it is at least prima facie acceptable for a state to produce weapons, and if it is acceptable for a state to produce weapons, it is acceptable for a state to eschew weapons production and purchase weapons from abroad, which a state has a good reason to do when it lacks a comparative advantage in weapons production.

The arms trade, then, can be justified by appeal to the right to security. ${ }^{12}$ States are permitted to purchase weapons either because doing so is (i) necessary to protect their citizens' security, or (ii) the most efficient way of protecting their citizens' security. And in order for a state to be able to purchase weapons, others must be permitted to sell weapons. (A state is able to purchase weapons provided that there is at least one supplier, and irrespective of whether private firms are permitted to sell weapons in addition to state-owned firms, but the advantages associated with allowing multiple suppliers to compete in a market at least ground a presumption against denying firms permission to offer their services. $)^{13}$

So far, I have defended the moral permissibility of (a form of) the arms trade by appealing to the value of security. But that same value can be used to identify moral limits to the arms trade. More specifically, the value of security can be used to discern limits on the range of weapon-types which may permissibly be traded, and on the range of appropriate recipients of arms transfers. There is much to say about the latter issue, but, first, let us briefly address the former. All weapons are designed to incapacitate, injure, or kill, and so all weapons pose a threat to individuals' physical safety. But some weapons pose an unacceptably large threat to individuals who have not made themselves liable to attack, and who are thus not permissible targets. 
Paradigmatic examples of such weapons include land mines and nerve gas, both of which kill and maim indiscriminately. These weapons pose a threat which is either spatially- or temporallyextended to an unusual and excessive degree. Nerve gas generates harms which are highly diffuse; it can travel large distances and kill non-combatants far from the battlefield. The threat posed by landmines has a shorter range, but extends far into the future: people continue to be killed and dismembered by unexploded mines long after hostilities have ceased. Ammunition containing depleted uranium, which was used extensively by British and US forces in Iraq and the Balkans, also potentially falls into this category. Upon impact, depleted uranium shells release radioactive particles which are potentially cancer-causing, persist in the environment for decades, and can travel far from the site where they were originally released. ${ }^{14}$

It is not my intention to discuss this issue in any depth, for the primary question regarding weapons in this category is whether it is ever permissible to use such weapons, and thus whether they should be manufactured in the first place. But, given that these weapons exist, and that states possess them, it is worth at least acknowledging that if their use is impermissible, their sale is too. If, for agent-neutral reasons, it is impermissible to use a particular item, it is also impermissible to enable, and benefit from enabling, the use of that item by others. ${ }^{15}$

Let us now consider limits imposed by the right to security on the range of appropriate recipients of arms transfers. I noted earlier that the right to security imposes upon states a duty to protect the security of their own citizens. In addition to this duty, the right to security puts states under a duty to refrain from depriving any person, wherever she resides, of the substance of that right. Indeed, 'the core of the right [to security] is a right that others not act in certain ways $^{116}$, and, given their capacity to inflict great harm, states are certainly included amongst those others. Some states fail to honour this duty with respect to individuals living beyond their jurisdiction. They behave in an aggressive and provocative manner, waging unjust wars, arming 
rebel groups attempting to overthrow legitimate governments, and supplying weapons to terrorist organizations. Sometimes they engage in terroristic activity themselves. ${ }^{17}$

Some states violate the security rights of their own citizens. Some fail to provide an adequate degree of security, while others actively deprive their citizens of their security. Their police and military forces kill unarmed protesters, torture dissidents, beat prisoners, rape civilians, and engage in various other violent crimes. For many individuals, the very agent that is duty-bound to protect them represents the primary threat to their security. Indeed, acknowledgement of the threat states pose to their own citizens has recently prompted a shift of focus among scholars and international institutions from the security of states (state security) to the security of individuals (human security). ${ }^{18}$

While it is clear that duties generated by the right to security are violated by regimes which kill and injure innocent members of their own citizenry, or aggress against foreign countries, I submit that those duties are also violated by states which provide arms to regimes which kill and injure their own citizens or aggress against foreign countries. When a state arms such regimes it facilitates, and thus becomes complicit in, those regimes' crimes. States are therefore morally required to refrain from arming such regimes. ${ }^{19}$ In the following two sections, I hope to vindicate this claim. The proposition is, I think, intuitive enough, but it is vulnerable to a number of objections. I will focus on defending the claim that states must refrain from selling (and must prevent their citizens from selling) weapons to regimes which oppress their own citizens, but most of what I say also applies to states which aggress against other countries.

\section{II.}

The claim that states must refrain from arming oppressive regimes can be resisted in the following manner. One might argue that the duties generated by the right to security sometimes conflict, in the sense that situations sometimes arise in which a state must choose between 
discharging its security-related duties to its own citizens and discharging its security-related duties to citizens of other states. In such cases, the argument claims, states may permissibly opt to discharge their duties to their own citizens, at the expense of the fulfilment of their duties to the citizens of other states. Or, put more modestly, states may permissibly opt to discharge certain duties to their own citizens, at the expense of the fulfilment of certain duties to the citizens of other states. The argument continues: states can sometimes enhance the security of their citizens by providing weapons to oppressive regimes, because such regimes are sometimes willing to contribute to the suppression of terrorist threats. When states can enhance the security of their citizens in this way, they are duty-bound to transfer arms to oppressive regimes.

This argument can be used to defend recent US foreign policy decisions. Since the terrorist attacks of 11 September 2001, the US has increased arms supplies to a variety of oppressive regimes on the grounds that those regimes, if well equipped, can play a valuable role in the 'war on terror', and thereby positively contribute to the security of US citizens. As Rachel Stohl and Suzette Grillot observe, recent US arms export policy has put commitments to refrain from arming oppressive regimes

on the backburner in order to give highest priority to countries which are supporting US efforts in Iraq and Afghanistan and which assist in the eradication of international terrorist networks... An analysis of twenty-five countries that play strategic roles in the United States' global antiterror operations finds that the events of 11 September 2001 have dramatically increased US arms sales to countries that have been repeatedly criticized by the US State Department for human rights violations... In 2006, the US State Department reported that 'serious', 'grave,' or 'significant' abuses were committed by the government or state security forces in more than half of these twenty-five countries..$^{20}$

It is tempting to reply to the claim that sates have a duty to arm oppressive regimes when, by doing so, they can enhance the security of their own citizens by arguing as follows: a 
state's duty to enhance the security of its own citizens is a positive duty, whereas a state's duty to refrain from undermining the security of others is a negative duty, and that, other things being equal, honouring negative duties takes priority over discharging positive duties. This strategy has two weaknesses. First, some people will deny that the distinction between positive and negative duties carries much (if any) weight. And, second, it is not obvious that a state's duty to enhance the security of its citizens is best conceived of as a positive duty. One might maintain that there is a negative duty not to assume a particular role and then fail to perform the functions associated with that role ${ }^{21}$, that providing security is a primary function of the state, and that state officials therefore violate a negative duty when they decline to take measures necessary to enhance the security of their citizens. Given these weaknesses, I will criticize the claim that states must arm oppressive regimes when doing so conduces to their citizens' security without appealing to the distinction between positive and negative duties. I will identify four problems which the claim faces.

The first problem the argument encounters concerns its empirical claim that states can enhance the security of their citizens - and, more specifically, reduce the threat they face from terrorism - by arming certain oppressive regimes. In a recent discussion of trade-offs between security and liberty, Jeremy Waldron argues that those who recommend curtailing civil liberties in order to reduce the threat to security posed by terrorist organizations must show that the curtailments they propose will actually have a positive impact upon security. ${ }^{22}$ An analogous argument applies here. Those who advocate arming oppressive regimes on the grounds that doing so will enhance domestic security must be able to convincingly demonstrate that the security gains they envisage will actually be forthcoming. They must, in particular, be able to counter the common claim that arming a regime which a terrorist group opposes will actually increase that group's hostility towards us, swell its ranks, and strengthen its resolve. This will not be easy. 
A second problem concerns the argument's normative claim that states have a duty to arm oppressive regimes when doing so enhances the security of their citizens. This claim is problematic because the right to security is not plausibly conceived of as a right to be maximally secure. This is not just because, specified in such a way, the right to security could not be adequately reconciled with other rights (such as the right to privacy), or because, specified in such a way, it would generate duties which are, in an absolute sense, overly demanding. It is also because the interest in being maximally, as opposed to reasonably, secure is just not weighty enough to place others under a duty. To illustrate this point, consider the duties imposed upon a mother by her child's right to security. The mother may be able to enhance her child's security by hiring a guard to patrol the perimeter of their house; hiring a security guard might reduce the probability that a dangerous intruder will break in and pose a threat to the child. Moreover, hiring a security guard might not be financially burdensome (suppose the mother is quite wealthy), and we can stipulate that hiring a security guard would not violate anyone's rights (or wrong anyone in any other way). Still, provided that the probability of a house invasion is already low - suppose the mother and child live in a reasonably safe neighbourhood, and other reasonable security precautions are taken (an intruder alarm has been installed, doors and windows are locked at night, etc.) - it just does not seem plausible to claim that the child's right imposes upon her mother a duty to hire a security guard. By hiring a security guard the mother goes beyond the call of duty; she provides her child with more than the adequate degree of security to which her child is entitled. The upshot of these considerations is this: in order to show that the right to security imposes upon states a duty to transfer arms to oppressive regimes it is not sufficient to show that such transfers will have a positive impact on security; rather, what must be shown is that arming oppressive regimes will ensure that people enjoy the adequate degree of security that the right to security is a right to. 
Suppose that the previous two problems can be surmounted. Suppose we have good reason to think that by arming oppressive regimes a state can increase, and not diminish, the amount of security enjoyed by its citizens, and that that extra security is owed as a matter of right. A third problem is that, in order to vindicate the provision of weapons to oppressive regimes, it must be shown that there are not acceptable alternative methods for generating the extra security which such provision offers. If a state has the means to provide the security to which its citizens are owed without arming oppressive regimes, advocates of the latter strategy must explain why those alternative means are unacceptable. ${ }^{23}$

The final problem is also the most serious. Suppose that our interest in a certain quantity of security is sufficiently weighty to impose upon our state a duty to provide us with that quantity of security. Suppose, too, that our state can only provide that quantity of security by supplying weapons to an oppressive regime. Even if these conditions hold, it does not follow that our state is under a duty to supply the weapons. This becomes clear when we notice that the duty which our interest in a particular quantity of security imposes upon our state has not yet been adequately specified. This duty is not plausibly conceived of as a duty to provide the relevant quantity of security whatever it takes, but rather as a duty to provide that quantity of security if and when it can be provided through morally permissible means.

Consider an analogy. Suppose I am expected to attend a close friend's wedding, and that, on the way to the ceremony, I get caught in a traffic jam. As a result of the delay I can only get to the wedding on time by driving at dangerously high speeds and running red lights. Clearly I am not permitted to drive at dangerously high speeds and run red lights. The set of options morally available to me is not expanded by the fact that the normal option-set is too restrictive to enable me to get to the wedding on time. Moreover, provided that I allowed myself a reasonable amount of time to travel to the wedding, and that the traffic jam could not have reasonably been foreseen, I think we should deny that by arriving late to the wedding I have violated a duty to my 
friend. If I had a duty to be on time, then clearly my late arrival would constitute a violation of that duty. But we should deny that I had such a duty, and say instead that I had a duty to pursue a morally permissible course of action which could reasonably be expected to get me to the wedding on time. (When we say that one has a duty to be on time to a friend's wedding it is, I suggest, this more nuanced duty that we actually have in mind. The shorter phrase is convenient short-hand.) I would violate that duty if I carelessly failed to leave myself enough time to travel to the wedding, or if I chose to take a particular route in the knowledge that there were likely to be delays along that route, and was late as a result. But I would also violate that duty if, after being innocently delayed by a traffic jam which I could not have reasonably anticipated, I proceeded to drive at dangerously high speeds and run red lights, thereby recklessly endangering other motorists and pedestrians. Similarly, by arming oppressive regimes a state violates its duty to provide a particular quantity of security if and when that quantity can be provided through morally permissible means.

Now, it might be objected that, in the case I described, driving dangerously fast and running red lights is impermissible because the harms it inflicts (including risks) are disproportionate to the harms I was trying to avoid (the disappointment my friend would feel if I missed his wedding). But, it might be argued, dangerous driving would be permissible in a case in which the harms (including risks) it inflicts were proportional to the harms the driver sought to prevent. Suppose there is a man in my car who will die unless he receives immediate medical attention. In such a scenario, it seems that I would be morally permitted to drive in a manner which imposes upon other motorists and pedestrians a degree of risk that is higher than that which could permissibly be imposed in less exceptional circumstances. Analogously, it might be argued, it is permissible for a state to inflict the harms associated with arming an oppressive regime when those harms are proportional to the expected harms it seeks to prevent befalling its own citizens, and the harms the US inflicts, or contributes to inflicting, when it arms oppressive 
regimes are proportional to the expected harms it seeks to prevent - namely, the harms which its citizens would suffer if they fell victim to a terrorist attack.

I do not find this argument convincing. I agree that it is permissible to drive in certain ways which would otherwise be impermissible if one is trying to get a dying man to a hospital, but considerations about proportionality do not do all of the work in grounding this judgement. In order for one's dangerous driving in such a scenario to be permissible it must be the case that the harms (including risks) which one inflicts are limited in size. Even in such exceptional circumstances, one is not permitted to drive with complete disregard for the safety of other motorists and pedestrians: one must still drive with an adequate degree of due care and attention. The point can be brought more sharply into focus with a further example. Consider a child who will die unless she receives a heart transplant. If the child's mother kills someone in order to give that person's heart to her child, the harms she inflicts are proportional to the harms she aims to prevent. But no one would think it anything but obvious that the mother acts impermissibly.

The thought underlying this conviction is that, except perhaps in the most exceptional of circumstances, it is simply impermissible to inflict certain, serious, harms upon innocent individuals, even if, by inflicting such harms, one could prevent comparable harms from befalling others. Do the harms generated by weapons transfers to oppressive regimes fall into this category? I think that, at least in certain (not unrepresentative) cases, our answer to this question must be affirmative. One country which received large quantities of US weapons in the aftermath of $9 / 11$ is Uzbekistan, a country presided over by an authoritarian regime which is regularly accused of serious human rights abuses. ${ }^{24}$ Here is a short excerpt from the US State Department's 2006 Human Rights Report for that country.

The government's human rights record, already poor, continued to worsen during the year. Citizens did not have the right in practice to change their government through peaceful and democratic means. Security forces routinely tortured, beat, and otherwise mistreated detainees 
under interrogation to obtain confessions or incriminating information. In several cases, authorities subjected human rights activists and other critics of the regime to forced psychiatric treatment. Human rights activists and journalists who criticized the government were subject to harassment, arbitrary arrest, politically motivated prosecution, and physical attack. The government generally did not take steps to investigate or punish the most egregious cases of abuse... The government continued to refuse to authorize an independent international investigation of the alleged killing of numerous unarmed civilians during the violent disturbances of May 2005.25

Elaborating, the report notes that 'torture and abuse were systematic', and that methods used by security forces included 'suffocation, electric shock, deprivation of food and water, and sexual abuse...' Security forces were accused of abusing human rights activists by 'dropping them onto concrete floors, forcing needles under their fingernails, suffocating them with gas masks, and burning their skin with lighted cigarettes, ${ }^{26}$

It is hard to imagine anyone denying that these are serious harms. Moreover, weapons transfers contribute to these serious harms in at least four ways: first, they provide tools with which security forces coerce, maim, and kill; second, they increase the power of the state relative to internal dissident groups; third, they increase the power of the state relative to members of the international community which may wish to intervene to protect basic rights; fourth, arms transfers constitute a form of international cooperation, and thus demonstrate that such cooperation is not contingent upon respect for basic rights: they counteract any verbal exhortations made by the exporting state, and reveal that opportunities for cooperation will be forthcoming irrespective of whether basic rights are respected.

With these considerations in mind I resubmit my original claim: states are morally required to refrain from selling weapons to oppressive regimes. When states provide arms to oppressive regimes such as the one in power in Uzbekistan they enhance and sustain grave 
threats to the security of the individuals who are subject to the power of those regimes, and thereby contribute to the infliction of serious harms which may not permissibly be inflicted.

\section{III.}

In this section I consider two further objections which can be pressed against the claim just propounded, namely, that states must refrain from selling weapons to oppressive regimes. First, it might be argued that arms sales to oppressive regimes can pave the way to improvements in the human rights practices of those regimes. When a state transfers weapons to an oppressive regime, it can win favour with that regime, and request that it reciprocate in certain ways, e.g. by being more respectful of human rights. I do not think that anyone willing to think objectively about these matters will take this argument very seriously. It might be true that, under certain circumstances, certain oppressive regimes will be willing to do certain things in return for weapons, especially if those weapons are provided at a discounted price. But there are a wide variety of incentives which states can offer in an attempt to influence the behaviour of oppressive regimes, and common sense indicates that weapons - tools which increase the ease with which oppressive regimes can violate the rights of their subjects - are among the least appropriate of those incentives.

A second argument runs as follows. Given that oppressive regimes will inevitably acquire weapons from somewhere, they may as well acquire them from us (i.e. liberal democratic states). Indeed, the argument continues, an oppressive regime purchasing arms from us is preferable to an oppressive regime purchasing weapons from another oppressive or illiberal regime. The largest five arms exporters are Britain, France, the US, Russia, and China ${ }^{27}$, and, according to the current argument, it would be better for an oppressive regime like Uzbekistan to enter into an arms agreement with one of the three relatively liberal democracies on that list than to enter into an arms agreement with Russia or China. This is for a variety of reasons. First, as we have just noted, arms exporters may be able to exert some degree of influence over their trading partners, 
and it would be better for an oppressive regime to be influenced by a liberal democracy than by another oppressive or illiberal regime. Second, the revenues Russia and China derive from arms sales to oppressive regimes will be used, inter alia, to augment their own arsenals. If we are concerned to minimize the quantities of weapons acquired by oppressive and illiberal regimes (and minimization is the only realistically achievable goal), we should do our best to deny such regimes access to the funds needed to buy and produce weapons, even if that means stealing their would-be trading partners in the international arms market - which may well be other oppressive regimes. Third, successful sales boost the profits of our arms industry, irrespective of who those sales are to, and our arms industry can invest those profits back into production of weapons systems for use by our own armed forces, and thereby enhance our security.

One way to respond to this argument is to reject its consequentialist reasoning, but it can also be challenged on its own consequentialist terms. Three points should be acknowledged. First, states will buy weapons from the firm which offers them the best deal. When firms compete for a particular customer they will often drive down their prices in order to match those offered by their counterparts. By permitting our firms to offer weapons to an oppressive regime, we increase the competitiveness of that particular market, and thereby enable the regime in question to acquire weapons at a lower price, and thus a larger quantity of weapons, than it would otherwise have been able to acquire. (One weakness of this argument is that, if we permitted our firms to drive down prices, we would also reduce the income which oppressive states may derive from arms sales.) Second, we may possess certain types of weapons, or weapons of a particularly high quality, which other potential suppliers lack. This is certainly true of the US. Thus, by transferring arms to an oppressive regime the US enables it to become more effective at oppressing its subjects than it would otherwise have been. Third, by trading arms with an oppressive regime we forego any possibility of persuading third parties to refrain from engaging in such trade. If we demonstrate a willingness to surrender the benefits of trading with 
certain oppressive regimes, we may have a chance of convincing others to surrender those benefits too. The moment we provide weapons, that chance vanishes. ${ }^{28}$ Relatedly, at our disposal are a variety of coercive economic measures which may be used against those who trade arms with particular oppressive regimes. But clearly we could not employ such measures if we were also trading with those regimes.

The two objections considered in this section fail. Selling weapons to oppressive regimes cannot be defended on the grounds that doing so may lead to improvements in the human rights practices of those regimes, or on the grounds that oppressive regimes will inevitably be able to acquire weapons from some source or other. Therefore, my initial claim stands: states are morally required to refrain from selling weapons to oppressive regimes.

\section{IV.}

In the previous two sections I argued that in order to respect the right to security possessed by individuals subject to the power of oppressive regimes, states must refrain from providing arms to such regimes. In this section I consider the moral permissibility of transferring arms to rebel groups waging revolutionary war against oppressive regimes. A concern for the security rights of those ruled by oppressive regimes gives us a prima facie reason to welcome the overthrow of those regimes, and to support the groups attempting to overthrow them. But that same concern also casts doubt on the strategy of supporting those groups by arming them.

Before I proceed, one clarification should be made. In what follows, I do not distinguish between trading and the broader notion of transferring. States often simply give, rather than sell, weapons to rebel groups, and if one thinks there is sometimes a moral duty to supply weapons to rebel groups that duty is surely best conceived of as a duty to give weapons free of charge, rather than as a duty to supply weapons in some way, including via the market. But, for present purposes, the distinction between trading and transferring is not germane. The issues I raise 
concern the provision of weapons to rebel groups per se, not the manner of that provision, and I will tend to speak simply of 'arming' rebel groups.

Given that arming is one form of supporting, determining (a) if and when it is permissible to arm rebel groups involves (b) determining if and when it is permissible to support rebel groups in some way. My intention is to focus on the distinctive issues which arise in relation to the former concern, but one general point about supporting rebel groups needs to be made first. If supporting a rebel group is to be permissible, it seems clear that several conditions, adapted from traditional just war theory, must be satisfied: the rebel group must have a just cause - the aim of the group cannot be to overthrow one oppressive regime and replace it with another; the harms which will occur if the rebels, with outside assistance, continue to fight must be proportional to the harms which the war effort can be expected to prevent; the war must be necessary - alternative means of overthrowing the regime must be unavailable; and it must be reasonable to expect that the rebel group, at least if it receives outside help, will not deliberately inflict violence upon non-combatants. These conditions will be relevant in what follows.

Arming a rebel group might be impermissible even if supporting it in other ways is not. This might be true for a variety of reasons, but I shall focus on one. Arming rebel groups has a notable shortcoming which some other means of support do not share, viz. the advantages conferred by certain forms of support can be terminated at any time, but the advantages conferred by the provision of weapons cannot. Compare and contrast three states, one of which supports a rebel group by providing arms (state A), one of which supports a rebel group by providing troops to fight alongside the rebels (state B), and one of which supports a rebel group by providing air support (state C). If state B decides at some point that it no longer wishes to support the revolution, it can simply recall its troops. Similarly, if state C decides that it no longer wishes to support the revolution it can simply recall its jets. State A, by contrast, is in a very different situation. It cannot simply ask for its weapons back. It can refuse to provide additional 
weapons, of course, but there is little it can do about the weapons it has already sent: it lost control of those the second they entered rebel hands. It is true that the ammunition A provided will eventually run out. But that does not change the fact that the advantages provided by A's policy extend into the future in a way which the advantages provided by $\mathrm{B}$ and $\mathrm{C}$ do not. And while the ammunition will run out, the weapons themselves can be used again and again. One can imagine a future world in which weapons feature self-destruct mechanisms which can be remotely triggered. In such a world, state A could cease its provision of support for the rebel group as easily and immediately as states B and C. But until such technical innovations come about, states which support rebel groups by providing arms suffer the disadvantage I have mentioned.

Why are these considerations morally salient? It was noted earlier that certain conditions must be met if support for a rebel group is to be permissible. The important point to acknowledge now is that those conditions, or at least some of those conditions, might obtain one day, but not the next. For example, at time $\mathrm{T}$ it might be reasonable to believe that the rebel group one is contemplating supporting will not deliberately inflict violence upon noncombatants, but at time $\mathrm{T}+\mathrm{n}$ it might became painfully clear that that belief was unfounded. $\mathrm{A}$ rebel group which had hitherto behaved in a morally appropriate manner might suddenly start engaging in attacks on civilians. Such a scenario is not at all improbable. As Allen Buchanan has recently explained, rebel groups often face strong pressures to engage in immoral conduct, and those pressures can intensify over time. This can happen if, for example, the regime the rebels are trying to overthrow attempts to dissuade people from participating in the revolution by increasing the penalties it imposes on those who engage in revolutionary activity. When a regime does this, rebels have a strong incentive to impose penalties on those who do not take part in the revolution: doing so may be their only way of maintaining participation at adequate levels. ${ }^{29}$ If the penalties the rebel group decides to impose are excessive - if, say, it decides to execute those 
who refuse to participate - continuing to support the revolution will be morally unacceptable, and states wishing to honour their moral obligations will wish to terminate support. Now, states which have supported the revolution by sending troops or jets will be able to terminate support immediately; by contrast, states which have supported the revolution by providing weapons will not.

It might be objected that the contrast I have drawn between a state which supports a revolution by sending troops or fighter planes, on the one hand, and a state which supports a rebel group by providing weapons, on the other, is not as sharp as I have suggested. It might be pointed out, for example, that a state which sends troops to assist rebel fighters cannot revoke the advantages it has already conferred - it cannot change the fact that its troops have, say, killed numerous regime soldiers - and so its situation is no different to that of a state which sent weapons. This objection misses the point. It is true that a state which sent troops or jets to support a rebel group cannot, at time $\mathrm{T}$, revoke advantages which its policy conferred at time $\mathrm{T}$ - n. But that is also true of a state which sent weapons. The point is that a state which sends weapons has committed itself to continuing to confer further advantages well into the future, whether it wants to confer those advantages or not. To put the point crudely, weapons are a gift that keeps on giving.

I should stress that my aim here has not been to show that supporting rebel groups by sending troops or providing air support is better, all things considered, than supporting rebel groups by providing them with weapons. I have described other methods of supporting rebel groups solely for the purpose of illustrating a distinctive problem with arming them, and I have not meant to suggest that these other methods do not have their own distinctive shortcomings: they certainly do. Aerial bombing, for example, comes with a high risk of civilian casualties. It should also be noted that the problem I have identified with transferring weapons also applies, mutatis mutandis, to some other methods of support. For example, if a state trains members of a 
rebel group in combat it cannot then 'untrain' them if it decides it no longer wishes to provide assistance. Intervening in revolutions is fraught with difficulty, and all methods of support have attendant risks. It is, nevertheless, important to emphasize the dangers associated with the provision of arms, for that strategy is often perceived to be superior to more direct forms of military intervention which tend to be eschewed when possible on the grounds that they put troops in harm's way, upset the electorate, and are extremely expensive. The US has recently supplied weapons to rebel forces in Syria but has resisted calls for other types of action. The upshot of the considerations adduced here is that providing arms should not be regarded as an unproblematic way of assisting rebel groups which is necessarily preferable to other available methods. By transferring weapons to a rebel group states provide that group with the means to violate the security rights of their fellow countrymen and countrywomen. Provided that the war the rebels are waging meets the criteria adumbrated above, a state supplying weapons does not violate negative duties generated by the right to security. But it must acknowledge the risks associated with arming rebel groups, and take those risks seriously when deciding what course of action to take. They must do their best to ensure that their intervention does not undermine the physical safety of the very people they are seeking to help.

\section{Conclusion:}

We have seen that the arms trade has an important role to play in ensuring that that right to security is protected. But we have also seen that the right to security generates duties to restrict the arms trade in significant ways. Weapons which pose a disproportionately large threat to noncombatants must not be traded, and weapons should not be sold to oppressive regimes. We also saw that while we may have good reasons to support rebel groups attempting to overthrow oppressive regimes, supporting such groups by arming them is, from a moral perspective, highly problematic. 
${ }^{1}$ I am very grateful to Simon Caney for his generous and helpful feedback on earlier drafts of this paper. I also owe a debt of gratitude to two anonymous referees, both of whom offered insightful comments.

${ }^{2}$ See, for example, Mathias Risse, 'Fairness in trade I: obligations from trading and the pauper-labor argument', Politics, Philosophy \& Economics, Vol. 6, No. 3, 2007; Malgorzata Kurjanska and Matthias Risse, 'Fairness in Trade II: Export Subsidies and the Fair Trade Movement', Politics, Philosophy \& Economics, Vol. 7, No. 1, 2008; Fernando R. Teson, 'Why Free Trade is Required by Justice', Social Philosophy and Policy, Vol. 29, No. 1, 2012; Aaron James, Fairness in Practice: A Social Contract for a Global Economy (Oxford: Oxford University Press, 2012); David Miller, 'Fair trade: what does it mean and why does it matter?' in J. Pearson (ed.), Fair Trade and Global Justice (Basingstoke: Palgrave Macmillan, forthcoming).

${ }^{3}$ Daniel M. Hausman and Michael S. McPherson, Economic Analysis, Moral Philosophy, and Public Policy: Second Edition (New York: Cambridge University Press, 2006), pp. 12-23; 259-273; Debra Satz, Why Some Things Should Not be For Sale: The Moral Limits of Markets (New York: Oxford University Press, 2010), pp. 109-10.

${ }^{4}$ Simon Caney, 'Markets, Morality and Climate Change: What, if anything, is Wrong with Emissions Trading?', New Political Economy, vol.15, no.2, 2010; Simon Caney and Catherine Hepburn, 'Emissions Trading: Unethical, Ineffective and Unjust?', Royal Institute of Philosophy Supplement, vol.69, 2011

${ }^{5}$ Leif Wenar, 'Property Rights and the Resource Curse', Philosophy \& Public Affairs, Vo. 36, No. 1, 2008

${ }^{6}$ The arms trade is briefly discussed by Thomas Pogge, who suggests that the 'arms privilege', which 'recognizes any person or group in effective control of a country ... as entitled to use state funds to import the arms needed to stay in power', is one aspect of the global order which harms the world's poor. See Pogge, 'Severe Poverty as a Human Rights Violation', in Pogge (ed.) Freedom from Poverty as a Human Right: Who Owes What to the Very Poor? (New York: Oxford University Press, 2007), p. 51.

${ }^{7}$ This position is taken by the Campaign Against the Arms Trade (CAAT). See http://www.caat.org.uk/

${ }^{8}$ For this conception of the right to security see Henry Shue, Basic Rights: Subsistence, Affluence, and US Foreign Policy (Second Edition) (Princeton, NJ: Princeton University Press), pp. 20-22. For a more expansive conception of the right see Jeremy Waldron, Torture, Terror, and Trade-Offs: Philosophy for the White House (New York: Oxford University Press, 2010), Ch. 5. I will add some depth to the notion of security as I proceed.

${ }^{9}$ Shue, op. cit., p. 21

${ }^{10}$ It might be argued that a state can protect the security of its citizens without possessing weapons of its own. It could do this by entering into an agreement whereby its citizens are protected by the security forces of another state. But few people would be willing to surrender responsibility for their security to another sovereign state - many 
people are unwilling to surrender responsibility for their security to their own state -, for a situation could arise in which that state is no longer able or willing to fulfil its obligations. This is not to deny that states are often dependent to some degree upon their allies for protection, but simply to point out that states are typically eager to avoid complete dependence.

11 Stohl and Grillot, op. cit., p. 22

12 The right to security may sometimes ground a right to weapons which is not conditional upon the ability to pay. If a legitimate state is unable to afford the weapons it needs to protect its citizens from unjust aggression, the international community may have a duty to provide weapons free of charge. It will have this duty if other ways of protecting the threatened individuals are unavailable or suboptimal.

${ }^{13}$ An anonymous referee has suggested to me that arms markets can be criticized on the grounds that they enable firms to profit from injustice: arms companies profit when states purchase weapons from them in order to protect themselves against unjust aggressors. But notice that this is by no means a distinctive feature of arms markets. Insurance markets also enable private firms to profit from injustice; as do markets in locks and intruder alarms: firms operating in these markets profit because some people refuse to respect the property rights of others. Yet no one proposes abolishing these markets. This is because we believe that concerns about profiting from injustice are outweighed by countervailing considerations. My intuition is that the same is true for arms markets. In any case, my aim in this paper is to identify restrictions on the scope of arms markets which can be grounded in the same value which justifies arms transfers in the first place, namely, the value of security.

${ }^{14}$ Sandra S. Wise et al, 'Particulate Depleted Uranium Is Cytotoxic and Clastogenic to Human Lung Cells', Chemical Research in Toxicology, Vol. 20, No. 5, 2007; Randall R. Parrish et al, 'Depleted uranium contamination by inhalation exposure and its detection after $\sim 20$ years: Implications for human health assessment', Science of the Total Environment, Vol. 390, No. 1, 2008

15 One complication arises from the fact that it might be permissible to possess and threaten to use certain weapons, even if it would be impermissible to follow through with that threat. This might well be true of nuclear weapons, which represent a special category of weapons. Given the spatially- and temporally-extended nature of the threat posed by nuclear weapons, and the severity of the harm they can inflict, the use of nuclear weapons is surely impermissible. But threatening to use nuclear weapons might be permissible precisely because such threats render the use of nuclear weapons less likely. Perhaps what we should say is that it is impermissible to sell (and thus enable others to use) weapons which it is impermissible to use unless one can be reasonably sure that the states to which 
one sells those weapons will not actually use them. Or at least we should say this about nuclear weapons, which occupy a special category all of their own.

16 Shue, op. cit., p. 39

${ }^{17}$ On terrorist states see Robert E. Goodin, What's Wrong with Terrorism? (Cambridge: Polity Press, 2006), Ch. 4.

${ }^{18}$ Ved P. Nanda, 'Preemptive and Preventive Use of Force, Collective Security, and Human Security', Denver Journal of International Law and Policy, Vol. 33, p. 10. The idea of human security is usually thought to possess multiple dimensions. We can endorse some aspects of the human security approach while rejecting others. For example, we can agree that security should refer, in the first instance, to the safety of individuals, and only derivatively to the integrity of state institutions, without signing up to the inadequately discriminative idea that security refers to protection from all kinds of threats, including threats from poverty and disease.

${ }_{19}$ An especially difficult question concerns the provision of weapons to states which are legitimate (and which, a fortiori, discharge their security-related duties to the degree that they are able to do so) but are also unstable (i.e. are liable to being overthrown by (unjust) internal or external aggressors). On the one hand, unstable states may have an especially strong claim to weapons transfers by virtue of the fact that they may urgently need weapons in order to protect their vulnerable position. But, on the other hand, there is a strong risk that any weapons transferred to unstable states will fall into the hands of unjust agents if and when those states are overthrown. A state may be legitimate at time $\mathrm{T}$, when weapons transfers are made, but illegitimate at $\mathrm{T}+\mathrm{n}$, after the machinery of government has been taken over by militants. A related concern is discussed in more detail in section IV, which considers the permissibility of transferring weapons to rebel groups seeking to overthrow oppressive regimes.

${ }^{20}$ Stohl and Grillot, op. cit., pp. 34-35 (footnote omitted)

21 Thomas Pogge, 'Are We Violating the Human Rights of the World's Poor?', Yale Human Rights and Development Law Journal, Vol. 14, No. 2, 2011, p. 11

22 Waldron, op. cit., pp. 44-45

${ }^{23}$ States have at their disposal a wide variety of strategies for protecting their citizens from terrorist attack. See Ronald D. Crelinsten, Counterterrorism (Cambridge: Polity Press, 2009).

${ }^{24}$ Stohl and Grillot, op. cit., p. 35

25 US Department of State, Country Reports on Human Rights Practices: Uzbekistan, 2006 (March 6, 2007), available here: http://www.state.gov/j/drl/rls/hrrpt/2006/78848.htm

${ }^{26} \mathrm{Ibid}$.

${ }^{27}$ Stohl and Grillot, op. cit., p. 3 
${ }^{28}$ A related point is made in Jonathan Glover, 'It Makes No Difference Whether or Not I Do It', Proceedings of the Aristotelian Society, Supplementary Volumes, Vol. 49, 1975, p. 178.

${ }^{29}$ Allen Buchanan, 'The Ethics of Revolution and its Implications for the Ethics of Intervention', Philosophy \& Public Affairs, Vol. 41, No. 4, (2013) p. 319 